\title{
International and National Legislative Standards for the Protection of Women from the Social Consequences of Labor Migration
}

\author{
Dildora Olimjanovna Akhmedova \\ Trainee Researcher, Department of Social Work, National University of Uzbekistan named after Mirzo Ulugbek, \\ Tashkent City, Uzbekistan \\ http://dx.doi.org/10.18415/ijmmu.v8i3.2482
}

\begin{abstract}
Over the past decades, the migration policies of the main destination countries have become much more stringent. In developing and improving migration policies, destination countries faced a difficult task - to find a balance between two factors: free market interests and border control / national security. In the context of globalization in the market, there is a growing demand for cheap and legally uncontrolled labor, while migration policy pays more and more attention to border control and the expulsion of illegal migrants. Millions of migrants are looking for a way out in these difficult conditions, attracted by job opportunities in destination countries, but with little legal access to it. This has resulted in a high growth in illegal migration, which has had a positive impact on many sectors of the economy in destination countries, where they are accustomed to relying on a cheap and flexible labor force - people who agree to any working conditions and are deprived of legal protection. This article is written about the problems and their solutions in different countries of the world faced by women migrants.
\end{abstract}

Keywords: Women Migrants; Legal Mechanisms; Labor Migration; Best Practices

\section{Introduction}

In the modern process of globalization, the problem of migration is becoming more and more important. It is estimated that an average of 232 million migrants live in different countries of the world. Most of them are in the northern countries of the planet.

The analysis shows that the migration process tends to increase and decrease in certain periods and has a positive, negative, if necessary, political impact on the social life of a particular region, country, region. Therefore, the issues of legal regulation and management of the migration process require special attention.

Considering the rights and interests of citizens of the Republic of Uzbekistan, in recent years the state has taken concrete measures to ensure an effective system of external labor migration. In November 2018, Uzbekistan became a member of the International Organization for Migration. In addition, our 
parliament recently adopted a law "On the ratification of the Constitution of the International Organization for Migration”.

However, in our country, women migrants face various obstacles and inconveniences in the countries where they go to work, even in our country. This emphasizes the need to develop measures to address the problem of female migration as soon as possible, analyzing the legislative experience and problems of countries that have now made positive progress in this sphere.

\section{Literature Review}

Action is urgently needed to address the serious problems in labor migration, as in all areas due to the spread of COVID-19 infection, to ensure safe, orderly and targeted employment at home and abroad.

A labor migrant benefits not only his family, his homeland, but also the country in which he works. After the current crisis, there is a shortage of specialists from large foreign employers, especially in the field of agriculture, which seriously affects the socio-economic life of people. Even for a year after a pandemic, the situation may not return to its previous state. Therefore, it is necessary to jointly manage the situation with labor migration during and after the crisis. To manage the flow of labor migration, it is necessary to determine the directions of cooperation between employment agencies, employers and the state, as well as the tasks that they should perform.

After the crisis, the demand for employment agencies and their recruitment process will increase. It also increases the risk of some of them abusing their responsibilities when hiring people. To effectively manage the situation in these conditions, it is necessary to properly organize the work of sending migrants, in particular, to check their health. In this regard, there should be an agreement between the receiving and sending countries of migrants and the employment agencies to ensure the quality of work.

Another important aspect is to better understand the industries in which migrant workers work in order to create a safe and acceptable environment for women migrants [2].

\section{Discussion}

\section{Where Does the Mistreatment of Migrant Women Come from?}

Traditionally, a migrant is an individual, more often a man, who, under the influence of internal and external economic factors, decides to move forward in search of a place "where the grass is greener". It is recognized that a given "neoliberal subject" has freedom of choice - the ability to act and make decisions that shape his / her life -but this freedom of choice is considered to be of a mercantile nature [4].

This perception carries the risks of using or instrumentalizing migrants in programs designed to promote development in countries of origin [2]. In other words, if we see the value of migrants only in the fact that they send remittances, they become "slaves" of international development, instead of being its main participants or beneficiaries. Many of these programs do not pay attention to the living conditions and well-being of migrants in destination countries and do not create effective mechanisms for discussing important issues with migrants' participation and involving them in activities in countries of origin. 
The risks of instrumentalization of migrants increase in cases where women are the main participants in migration projects. Most often, women went unnoticed, and if they were considered, then as family members dependent on the decisions and plans of their migrant husbands [3].

Recently, the importance of women's participation in the migration process is beginning to be recognized as independent migrants, managers of remittances, or as persons leading the household in migrant families. However, the image of women migrants is still determined by many stereotypes and falsified.

\section{The UN Cited Several Misconceptions About Women Migrants and Introduced Amendments to Them:}

Misconceptions about women migrants and amendments:

1) Ability to act: the ability of women to make decisions (for example about migration) is assessed only from an economic point of view, and not in relation to their social status in the household, in the labor market or other areas.

\section{Amendment:}

Programs should not only stimulate women's participation in the labor market. They must also act at a structural level to remove conditions that limit women's participation, such as the division of unpaid labor, gender segregation in the labor market, and to expand their political representation (in the broadest sense)

2) Individualization. Migration is still often studied at the level of the individual. When migration is analyzed in a broader context as a household strategy, the ideal harmonious unit is considered - the traditional nuclear family. Other family models - the extended family or homosexual couples - are overlooked.

\section{Amendment:}

Migrants belong to different types of families and wide social networks in which their power relationships exist. Therefore, not everyone has the same opportunities or benefits from migration. It is important to research the position and civic participation of men and women in households and other social networks and spaces

3) "Victims and Bad Mothers". Women migrants are often represented only as victims (for example, victims of human trafficking) who lack the capacity for independent choice. They are sometimes denounced as bad mothers who abandoned their children in their countries of origin.

\section{Amendment:}

It is important to recognize and promote the potential and freedom of choice of migrant women, empowering them to make decisions and benefit from development processes. In this direction, one should not take the position of a moralist; instead, one should be guided by practical considerations.

As an alternative, the UN proposes: in order to turn "victims" and "slaves" into real driving forces (protagonists) of development, it is required to create for them the opportunity to independently make decisions and influence development processes, including the content and goals of the respective 
programs. It is also important to see them as beneficiaries of development, for example, paying attention to the living and working conditions of migrants [4].

\section{The Main Problems of Women Migrants}

The human development approach is closely linked to human rights, in particular, it views development as a comprehensive right to the unhindered enjoyment of all human rights. This approach has been adopted by all UN agencies, as well as by most development organizations. However, in practice, in accordance with the neoliberal and economic theories that underlie many development programs and strategies, economic development is usually given more attention than the expansion of human freedoms and opportunities [4].

By focusing solely on the impact of remittances on improving the well-being of families in countries of origin, scholars and others on the issue turn a blind eye to the fact that these improvements often result from the neglect of migrants' rights in countries of origin, transit and destination. In countries of origin, it is the denial of the right to development that often pushes people to migrate. For example, module 2 talks about the ability to determine which rights are not being respected (for example, the right to education, health care or social protection) by analyzing the budget lines on which the recipient households spend the money. For women, discrimination in the labor market, gender-based violence and tight control over their lives by older relatives are also important reasons for migration.

In the process of moving from one country to another, migrant women often face many challenges that affect their rights. Those traveling with a smuggler - a smuggling agent - may be abandoned by them in case of problems en route or upon arrival in the destination country. Women are also at risk of sexual and physical violence at the hands of smugglers, local authorities and others along the way in the transit country (CEDAW General Recommendation 26, paragraph 12). For example, women working in cross-border trafficking are most vulnerable to violence from smugglers, human traffickers, criminals, and border officials who have a duty to protect the rights of migrants.

In countries of destination, women migrants are also often unable to enjoy human rights. Imperfect migration policy contributes to the emergence of situations leading to violation of the law and victimization, which can be especially difficult for women. At the same time, the lack of regulation in the care sector, where the majority of women migrants work, leads to violations of their labor rights and the right to care. Finally, they lack or have limited access to health services, especially in the area of sexual and reproductive health, due to a number of factors [5].

\section{Best Practices for The Protection of Migrant Women from Different Countries}

In different countries, a number of laws or legislative acts have been adopted in this regard, which should facilitate the situation of women migrants. Here are some examples:

Tajikistan. The Center for Human Rights (CHR) is a non-profit organization registered by the Ministry of Justice of the Republic of Tajikistan on October 27, 1997. The main mission of the center is to assist in building the rule of law in Tajikistan by raising the legal awareness and legal protection of the population.

The priority program area is the protection of the rights of migrant workers, which is implemented at three levels. 
- Provision of free legal aid to migrant workers - women and men, as well as members of their families through the Migrant Assistance Center;

- advocacy at the national level in partnership with key stakeholders to advance the rights and interests of migrant workers and their families in the process of shaping migration policy;

- Advocacy of the rights and interests of Tajik migrant workers at the international level in the course of the work of the UN treaty bodies, platforms created in the framework of cooperation between the Government of Tajikistan and the EU, OSCE, etc.

Ireland. Domestic workers' action group: participation, empowerment, collective action.

In 2004, the Center for the Advancement of Migrants 'Rights in Ireland (MIPR) established the Domestic Workers' Initiative Group (DHRG) in response to an increase in their complaints to Migrants on employment issues that the government did not respond to.

IGDR is a Dublin-based organization with 200 members, mostly women migrants working in private homes. The IGDR aims to combat the exploitation that many domestic workers in Ireland face by empowering them to fight for better legal protections and working conditions.

The IGDR takes a holistic approach that includes informing all domestic workers about their rights, including the right to remuneration, and helping domestic workers obtain compensation for changing their situation by looking for new opportunities such as teaching childcare. IGDR's goal is to create a powerful organization that will represent the interests of domestic workers, fighting to enforce existing and new laws to improve the working conditions of domestic workers.

The core principles of IGDR are participation, empowerment and collective action. Participation is encouraged by providing domestic workers with a safe meeting space and relevant information on issues related to their work and immigration. Group members participate in planning activities, leadership development courses, social and fundraising events, as well as attending media trainings, photography and videography courses.

USA. Founded in 2000, United Domestic Workers (UDW) advocates for migrants from the Caribbean, Latin America, Africa working in New York as nannies, domestic workers and caregivers for the elderly. According to the organization's website, they "came together to achieve power, respect and decent work standards, and to help organize a global movement to end exploitation and oppression."

In August 2010, SDT made significant progress. The group secured the signing of what became known as the Domestic Workers Bill of Rights, which amended New York State law to guarantee basic labor and protection standards for nannies, caregivers, and domestic workers who contribute to the wellbeing of families. New Yorkers and make all other work possible. The Bill of Rights, which entered into force on November 29, 2010, is a comprehensive response to the vulnerability of domestic workers to exploitation and unfair treatment, and includes labor protection requirements for this category of workers. The bill contains provisions on working hours, rest days, paid vacation days, occupational health and safety, and the right to association [4].

Spain. The Health and Family Association (Salud y Familia) is implementing several programs to improve access to health services for illegal migrants living in the Barcelona area. To this end, the Association combines lobbying tactics and constant contacts with relevant organizations and government representatives. 
In collaboration with public hospitals in Catalonia, the Mothers Between Two Cultures program aims to develop and implement a pilot project of intercultural education for migrant mothers from different countries of origin with children under three years of age. The goal of the project is to expand coverage of maternal and child health services and promote the growth of the potential of migrants by raising the level of knowledge and support through social networks. This program has proven to be especially effective in adapting newly arrived migrants who know almost no one in their new country and often live in isolation. The Association also offers a program called "Support for Motherhood in Risk Situations", which helps pregnant women in obtaining the necessary care and psychological support.

Kazakhstan. An important step in improving the national legislation on regulating the activities of domestic workers was the adoption in December 2013 of the Law of the Republic of Kazakhstan "On Amendments and Additions to Certain Legislative Acts of the Republic of Kazakhstan on Labor Migration".

According to these changes, Article 214 of the Labor Code of the Republic of Kazakhstan clarifies the concept of "domestic workers" and also specifies such essential conditions of their work as working hours, rest time, the procedure for applying and removing disciplinary sanctions, resolving individual labor disputes, and terminating an employment contract. Compliance with these requirements is mandatory when concluding an employment contract not only with citizens of Kazakhstan, but also with foreigners.

\section{Legal acts in Uzbekistan}

In Uzbekistan, on August 20, 2019, a Presidential Decree "On measures to further strengthen the guarantees of protection of citizens of the Republic of Uzbekistan carrying out temporary labor activities abroad and their family members" was adopted [1]:

- It provides for the provision online to citizens who have expressed a desire to go abroad for temporary work, information on the rules of stay, working conditions, social and housing provision in the country of employment, legal aspects of concluding employment contracts with foreign employers, as well as measures financial support provided by law;

- providing information on the activities of the Agency and private employment agencies, including information on the types and costs of services they provide, vacancies available to foreign employers, as well as the procedure for employment at these jobs;

- monitoring of processes related to temporary labor activities of citizens of the Republic of Uzbekistan abroad, including information on the passage of vocational training, retraining and advanced training, measures of financial support received, legal and social assistance provided, as well as labor contracts concluded with foreign employers;

- the possibility of remote filing of appeals by labor migrants who have found themselves in a difficult situation abroad and who need help; formation of a database on labor migrants, geography of employment, directions and types of their activities;

- credits, subsidies, microloans and apartments in apartment buildings are provided to labor migrants registered in the "labor-migration" program complex.

\section{Conclusion}

In today's crisis, the coronavirus pandemic affects all countries, regardless of their level of economic development. This will certainly have a serious impact on labor migration, as in all sectors. 
It must be admitted that in recent years the government of Uzbekistan has held a number of negotiations with a number of countries in the field of external labor migration, in particular with the Russian Federation, and is achieving effective results. Russia is currently developing a new migration strategy. The problems faced by employment agencies and migrants will be reduced if the practice of screening Uzbek labor migrants traveling abroad is introduced.

\section{References}

1. On measures to further strengthen the guarantees of protection of citizens of the Republic of Uzbekistan carrying out temporary labor activities abroad and their family members. (2019). Decree of the President of the Republic of Uzbekistan. No. UP-5785, August 20. Retrieved from: https://lex.uz/docs/4482657

2. Tolametova Zilola Abdujabborovna (2016). International labor migration and its peculiarities. Economics and Finance (Uzbekistan). №3. Retrieved from: https://cyberleninka.ru/article/n/hal-arome-nat-migratsiya-va-unun-ziga-hos-sususiyatlari.

3. Labor migration: problems and their solutions. (2020). Official website of the Ministry of Employment and Labor Relations of the Republic of Uzbekistan, April 27. Retrieved from: https://mehnat.uz/uz/news/mehnat-migraciyasi-muammolar-va-ularini-echimlari

4. Gender Agenda in Migration: Relationship between Labor Migration and Development in the Context of a Gender Approach. (2011-2013). UN Women Training Center, Santo Domingo. p.283.

5. Labor migration: International experience and practice of Uzbekistan. (2018). Official site of the Legislative Chamber of the Oliy Majlis of the Republic of Uzbekistan, December 18. Retrieved from: http://parliament.gov.uz/uz/events/committee/24575/

\section{Copyrights}

Copyright for this article is retained by the author(s), with first publication rights granted to the journal.

This is an open-access article distributed under the terms and conditions of the Creative Commons Attribution license (http://creativecommons.org/licenses/by/4.0/). 